\title{
The Great War and Military Occupation: Rumänien im Wort und Bild-A German soldiers' propaganda magazine (1917)
}

La Grande Guerre et l'Occupation militaire : Rumänien im Wort und Bild, un hebdomadaire de propagande des soldats allemands, 1917

Marele Război și ocupaȚia militară: Rumänien im Wort und Bild - O revistă germană de propagandă a soldaȚilor germani (1917)

\section{Claudiu-Lucian Topor}

\section{(2) OpenEdition}

\section{Journals}

Electronic version

URL: https://journals.openedition.org/ceb/16396

DOI: $10.4000 / c e b .16396$

ISSN: 2261-4184

\section{Publisher}

INALCO

Printed version

ISBN: 9782858313693

ISSN: 0290-7402

\section{Electronic reference}

Claudiu-Lucian Topor, "The Great War and Military Occupation: Rumänien im Wort und Bild-A German soldiers' propaganda magazine (1917)", Cahiers balkaniques [Online], 47 | 2020, Online since 21 August 2020, connection on 06 July 2021. URL: http://journals.openedition.org/ceb/16396 ; DOI: https:// doi.org/10.4000/ceb.16396

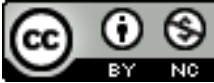

Cahiers balkaniques est mis à disposition selon les termes de la Licence Creative Commons Attribution - Pas d'Utilisation Commerciale 4.0 International. 


\section{The Great War and Military Occupation: Rumänien im Wort und Bild-A German soldiers' propaganda magazine (1917)}

La Grande Guerre et l'Occupation militaire: Rumänien im Wort und Bild, un hebdomadaire de propagande des soldats allemands, 1917

Marele Război și ocupația militară: Rumänien im Wort und Bild - O revistă germană de propagandă a soldaților germani (1917)

Throughout time, it has become obvious that there exists a complex relationship between propaganda, censorship and the effects of press information on the shaping of the public opinion. In particular, the perception of the modern war, of its costs, of the sacrifices, duration and consequences, has caused dramatic changes in the behaviour of individuals. Modern war is not merely a military clash between professional soldiers. It also involves a psychological confrontation for winning the "minds" and especially the "hearts" of people. All this with the help of refined means, which penetrate the depth of consciousness and influence the state of mind. The emergence of the "total war" in the $20^{\text {th }}$ century inevitably led to the manipulation of the press for political purposes. The warriors were now demanding from civilians their complete commitment for their frontline efforts. This is why the nation's state of mind had to be maintained through propaganda actions. In both world wars of the $20^{\text {th }}$ century, the press has acted willingly for disseminating the propaganda justifying the goals of the wars and supporting the soldier's morale. The war reportage, the frontline reporting payed less attention 
to truthfulness (yellow journalism was proliferating!) than to the advantages of manipulation. ${ }^{1}$

\section{The German press at the beginning of the war}

Immediately after the outbreak of war in 1914, the German press policy entered a process of thorough reorganisation. Helmuth von Moltke (Moltke the Younger), the head of the Chiefs of Staff before the Marna battle, had noticed as early as August 1914 the need for a closer cooperation between the press and the leaders of the war operations. The press had become an indispensable instrument for frontline operations. However, the Ministry of War lacked its own press service. Kriegspresseamt was established relatively late (October 1915) and the entire reorganisation strategy was designed by Major (later Lieutenant-Colonel) Walter Nikolai, head of the News Department (Nachrichtenabteilung, IIIB), the officer in charge with press matters at the German Supreme Army Command (OHL). This officer published an account of his vast experience in a book called "Nachrichtendienst. Presse und Volksstimmung im Weltkrieg" [The News Service. Press and public opinion in the World War], printed in 1920 as a response to Heinrich Binder's brochure bearing the suggestive title „Was wir als Kriegsberichterstatter nicht sagen dürfen" [What we were not permitted to say as war correspondents]. The Berlin press was receiving daily briefings from the IIIB Division led by Walter Nikolai. The journalists would get official reports about the progress of war, according to the news arriving from the Supreme Army Command (OHL). They were dry accounts, with few details, which did not always correct "fundamental errors", because, as Walter Nikolai states, they could correct themselves in any future reports. Apart from these official reports, a whole host of correspondents would supply information from the theatre of war. The German newspapers thus had the opportunity of publishing more information about life on the frontlines and about the survival of troops on the battlefield. These accounts as well were subject to the strict rigours of censorship. The German press remained, until the end of the war, a consumer's product systematically delivered by the Kriegspresseamt. ${ }^{2}$ Fortunately, it was not the only type of press still alive.

\section{Frontline newspapers (trench journals)}

The specific circumstances of war also generated a parallel mechanism of information editing: the campaign press. Both in the Entente camp and in

1. Details in Hentea, 2014, p. 81-94.

2. Koszyk, p. 24-29. 
the camp of the Central Powers, the combatants printed (with scarce means) frontline publications. Their in-depth research began during the interwar years. Anne Lipp, in a book on manipulation and the experience of war, states that as many as 110 German campaign newspapers were published from September 1914 until 1918. She mentions in this context Karl Kurth's dissertation with the title Die deutschen Feld-und Schützengrabenzeitung des Weltkrieges [German field and trench newspapers in the World War $]^{3}$, the first proper research carried out into these historical sources, started for propaganda reasons (Karl Kurth was a member of the Nazi Party). The main part of Kurth's dissertation consists of an inventory of newspapers, with a brief description of the circumstances in which they were published. The work remains a unique source of information, because it uses archival collections that have meanwhile been lost, as a result of the destruction of the Military Archives in Potsdam (papers issued by the Kriegspresseamt and the Feldpressestelle). ${ }^{4}$ Anna Lipp's book (2003) remains the only fundamental study undertaken after 1937 on the topic of German campaign newspapers. The topic of propaganda in the trenches, however, became increasingly attractive for the history of culture. What Anna Lipp set out to do (to research the manner in which propaganda mechanisms affected the soldier's wartime experience), using as a primary source the campaign press, was carried on by Robert Nelson in a monograph analysing the apparition, contents and echo of such publications. The campaign newspapers were published by soldiers for soldiers, in the vicinity of the frontline. Their editors (not always in high positions in the army hierarchy), who had been working as teachers and journalists in their civilian lives, circulated the ideas of Wilhelmian conservatism and used an accessible language. The papers were targeting an exclusively male audience (the soldiers) engaged in a violent cataclysm (the war). They provided information about the reality on the front line and aimed to boost the morale of the combatants. The Germans recognised their usefulness. On 7 September 1914, East Prussia (besieged by the Russians) saw the first publication of this type appear, Kriegszeitung der feste Boyen und der Stadt Lötzen [The War newspaper of the Boyen fortress and of the city of Lötzen], followed one week later by the first newspaper to be published on the German lines on the French front [Hohnacker Neueste Nachrichten], the creation of a Chiefs of Staff sergeant (the poet Edmaier from München). The publication, well received by the Bavarian company it was part of, was renamed Bayerische Landwehrmann [The Bavarian Infantryman], once the combat outfit moved to Belgium. In time, its print run increased (2000 copies) and it became the battalion's newspaper after

\footnotetext{
3. 1937, Noske, Leipzig.

4. Lipp, p. 27.
} 
it returned to the Vosges. Campaign newspapers were published in all the places in Europe where the German forces had military operations. And this included the Eastern front. The newspapers here had a much different image compared to those in the West. The editors agreed, for instance, that the publication „Liller Kriegszeitung" was a much varied and cultivated newspaper that its Eastern counterpart („Feldzeitung der Bugarmee”/The field newspaper of the army on the river Bug; or the „Deutsche Kriegszeitung von Baranowitschi”/The German campaign newspaper for Baranavichy), because it belonged to the Western culture, which was significantly superior. ${ }^{5}$

\section{The press of the German military occupation in Romania}

Campaign newspapers were followed by a different type of press (the military occupation newspapers) everywhere German administration was put in place. The operations army newspapers were replaced by the press published by the occupation forces. This species of journalism, an effective propaganda vehicle, fits into an intermediate category, located between the publication of civilian newspapers (the opinion press behind the front lines) and the troops' newspapers. The military occupation press targeted both the German readers (soldiers, officers, administrative clerks, local German-speaking population, civilians back home etc.) and, specially, the local population. Romania, governed by the Germans in two thirds of its territory, was the "beneficiary" of such a press. Documents in the Romanian military archives mention the newspapers and their illustrations, together with pamphlets, letters and photographs, as basic instruments for German propaganda in the occupied territory. Of the newspapers circulating during the military occupation, some targeted the Romanian-speaking audience, but others addressed exclusively those who read in German, French and even Russian: "Gazeta Bucureştilor"/Bukarester Tagblatt; "Lumina”; "Timpul”; „Putna Zeitung“; „Donau Armee Zeitung“; „Der Bund“; « Gazette des Ardennes »; « L’Indépendence Helvétique »; “Gazette de Lorraine », „Rumänien in Wort und Bild“. ${ }^{6}$

For the German soldiers, the Romanian front was a little-known world. Gundula Gahlen reflects on the manner in which the German soldiers experienced the Romanian campaign. To begin with, they lacked a detailed image of their enemy. Before the war, Romania (both the country and its people) had not been

5. NeLson, p. 5-7; p. 16-21.

6. Romanian Military Archives, fonds "Marele Cartier General" ("General Headquarters"), file nr. 1195, leaves 13-14. See, "Propaganda germană pe frontul român”. Document issued by the Intelligence Department, 1917. 
made familiar to the German society at large; it was known only by a limited group, that of elites. The war propaganda was ruthless, disseminating intensely deprecating images of Romanians, stereotypes capable of clearing any doubt about the meaning of the Eastern campaign. Thus, the Romanian front was not a secondary theatre of war, the German soldiers' sacrifice was not in vain, they had to avenge the enemy's "betrayal" and the "dastardly" attack on Austria-Hungary. The intense insistence on the rationale of war, however, did not manage to clarify the picture of the cultural environment in which the battles were being waged. The Romanian front remained, by and large, an unknown world. The German soldiers had encountered a population whose language, traditions and customs they did not understand. The geographic disorientation enhanced the feeling of culture shock. The Romanian realities, apparently similar to those on the Serbian front and in Russia, deepened the sense of estrangement. It seemed to be, indeed, a world belonging to a different historical era, a place in which the poverty of ordinary people contrasted with the fertility of the land. ${ }^{7}$ When the fighting ceased temporarily and the victory of the Central Powers was partially secured, governing the new territories also demanded an effort of detailed information gathering.

Maria Bucur argues that the German military occupation caused a substantial change in the Romanian cultural life, to the benefit of the Central Powers. Shortly after Bucharest was occupied, the building of the National Theatre was requisitioned, and so were fashionable cafes, restaurants, cabarets, and nightclubs, which became German casinos opened mainly for German officers. ${ }^{8}$ The fate of the press was not much better. The former building of the daily "Adevărul" (requisitioned) now served for the printing of military occupation dailies: "Bukarester Tagblatt", with its Romanian version "Gazeta Bucureştilor". Lysa Mayerhofer estimated that in June 1917 the print run of the two dailies reached 95000 copies, of which approximately 40000 were in German and 55000 in Romanian. The Romanian population was encouraged to buy "Gazeta Bucureştilor" by the ordinances issued by the German Command (Kaiserliche Kommandantur der Festung Bukarest) and by the fact that the daily published war prisoner lists. At the same time, the publication of news (in the form of classified ads) for the Romanians in the unoccupied territories had given ride, starting with September 1917, of an illusion of a stable connection across frontlines. Apparently, some prisoners of war stated that "Gazeta Bucureştilor" allegedly reached (in numerous copies) the

7. GAHLEN, 2009, p. 137-159, here 145-147.

8. BUCUR, 1999, p. 243-367, here p. 256. 


\section{CAHIERS BALKANIQUES}

88

La presse allophone dans les Balkans

unoccupied part of Romania. But this is difficult to prove. ${ }^{9}$ What remains certain, however, is that the newspaper had quite a lot of subscriptions in the occupied territory. Gerhard Velburg remembered that "Bukarester Tagblatt" used to be the main provider of "spiritual sustenance" for the troops in the Bărăgan Plains. The newspaper would reach Feteşti (in Ialomiţa) by post around noon, instantly occupying almost all writing desks. Every soldier had a subscription!

We had started taking as intense an interest in the small events taking place in Romania as we were taking in those in Germany, and even greater almost, because who is to say we won't spend a considerable part of our lives here [...] Therefore we read about who has been born or has died in Bucharest, who has become engaged or got married-these things are still happening-where was the latest fire and which fireman led the rescue operations, what is on the playbill at the theatre or at the cinema, who broke the law and how they paid for it. ${ }^{10}$

Lieutenant dr. Rudolf Dammert was appointed chief editor of "Bukarester Tagblatt". He had already published (in 1916) in Leipzig a brochure about the war (Der serbische Feldzug. Erlebnisse deutscher Truppen/ The Serbian campaign. The experience of the German troops), and while in Romania he also took on the editing of the weekly Rumänien im Wort und Bild. Long after the war, in 1938, Dammert published a book (Deutschlands Nachbarn in Südosten. Völker und Mächte in Donauraum/ Germany's neighbours in the South-East. Peoples and powers in the Danube space), based on the information he had acquired about South-East Europe. ${ }^{11}$

\section{Rumaenien im Wort und Bild (RWB)}

It was the offices of Bukarester Tagblatt that published the weekly magazine Rumänien im Wort und Bild (RWB). The publication targeted as much the German troops as the Romanian population. A version in the Romanian language, with the title "Săptămâna ilustrată" ("The Week Illustrated") was on offer for the local public. It is worth noting that the articles from the German version were not always translated integrally in the Romanian version. "Săptămâna ilustrată"

9. MAYERHOFER, p. 323-326.

10. Velburg, 1930, p. 169.

11. FASSEL, 2016, p. 242. 
appeared to me more closely connected to domestic propaganda purposes, as the main topic was showcasing the "benefits" brought to the country by the German administration. The first issue of the German-language magazine (12 May 1917) underlines that the publication aimed to serve to the German officers and soldiers as a guide to the occupied territory. At the same time, it addresses the local German residents and the subjects of the allied powers, who would thus have the opportunity of telling to the readers the "German fatherland" about their own experience in a country which, they hoped, the "victorious campaign" would turn, once again, into a rich and fertile land. To the Romanians, the magazine would show the compassion with which the Germans (often called "barbarians"), carriers of a foreign culture, were treating them. Towards the end of the inaugural editorial, the text leans towards reconciliation and pacifism. The editors express their hope that, shaking off blind hate, humankind will once again acknowledge the responsibility of its lofty mission and will start, from the very ruins of the battlefield, the rebuilding of the new Europe. ${ }^{12}$ Nevertheless, the effects of the publication among the Romanians remained insignificant. Even the Germanophile Alexandru Tzigara-Samurcaş, former prefect of Bucharest, classified RWB among the "peaceful activities of the occupying warriors" and thought it was "neatly printed", "attractive due to its varied, albeit biased contents". ${ }^{13}$

The German press in Romania, active in the years of military occupation, only occasionally made the object of historical research. Very little indeed has been said about RWB. The research concerning German propaganda in the war years generated multiple interpretations. Radu Tudorancea appreciated the outstanding quality of the RWB illustrations and argued that the articles published in the German weekly tried to induce a feeling of calm and normality among the local population. Due to the standards of the published articles, it appears that the magazine targeted mainly the educated public, although the Romanian personalities of the time (such as Nicolae Iorga) denied its scientific qualities and recognised only its informative merits. ${ }^{14}$ Lysa Mayerhofer identified four fundamental topics that had completely captured the interest of the press during the military occupation:

- the Europeanisation of Romania;

- the contrasts of its society;

- the "frivolity" of Romanians;

- the ethnic diversity of the population.

12. RWB, 1. Jahrgang, no. 1, Bukarest 12. May 1917.

13. Tzigara-Samurcaş, 1999, p. 202.

14. Tudorancea, 2016, p. 195. 
The RWB magazine discussed intensely all these themes. However, Lysa Mayerhoer only discusses the general picture of the occupation press. The contents analysis, the overview, do not set the publication apart from the general editorial mechanism of the era. ${ }^{15}$ This picture is provided, but also within a context, by the research carried out by Horst Fassel. He inventories mainly the cultural topics presented in the magazine: the personalities of the Romanian public life (politicians, artists, scientists); conferences and lectures held by German professors in occupied Bucharest; Romanian literary monuments; architecture and art exhibitions; activity in theatres, etc. ${ }^{16}$

As a propaganda instrument, the magazine (RWB) actually pursued two distinct goals: the justification of military occupation by assuming a civilizing role; the popularisation of positive images about the allies (Bulgarians, Turks, Austro-Hungarians) in order to strengthen ties within the winning coalition. As a plain source of information, the magazine presented to the public the image of Romania under military occupation, its historical past, but also the major events taking place in everyday life. RWB took thus on a cultural function as well, as it documented and disseminated among the German soldiers in-depth knowledge about the Romanian scene.

\section{The Germans and the civilizing mission}

Justifying the military occupation had become, in the war years, a genuine obsession for the Germans. Robert Nelson argued that the most striking difference between the allied newspapers and the German campaign press was always the focus on the rhetoric of justifying war and occupation. Unlike the French or the British, the Germans always viewed themselves as invaders. Their need to show they were fighting for a just cause became an obsession in frontline newspapers. ${ }^{17}$ As far as the German army campaign on the Eastern front is concerned, fighting against the Slavs involved definite ideological grounds. Jurgen Angelow considered that the negative stereotypes that had accented in the past the anti-Slav racist trends continued to live until World War II and contributed to the shaping of the German belligerents' image of their opponents. As far as Romanian is concerned, however, the author states that the events of the Great War challenge this undifferentiated image. Apart from the press, the combatants, memoirs and letters

15. MAYERHOFER, p. 323-344.

16. FASSEL, p. 242-249.

17. Nelson, p. 8-9. 
reveal both negative judgements and positive perceptions. ${ }^{18}$ The local civilians of Eastern Europe were often viewed as helpless children in need of learning how to govern themselves (the German way, obviously) from fully trained adults. ${ }^{19}$ The Germans' civilizing mission gradually floods the magazine's pages. The first issue (12 May 1917) presents a "before" image of Bucharest, 50 years previously [Bukarest vor 50 Jahre]. It is not by accident that this number is chosen, because the author aims, at all costs, to portray king Carol I himself as an "agent" of progress. The reader discovers the transition from an initial stage of a city with an Oriental appearance, with dusty, winding and narrow streets, with mud huts, to an European metropolis, famous in its elegance and good taste. ${ }^{20}$ Underlining Romania's backwardness compared to the civilization of Western Europe also served to legitimize from a moral point of view the military occupation. It made easier (and even justified!) the access to the country's natural riches. ${ }^{21}$ The Germans are presented as architects of reconstruction. They are mending whatever the Romanian soldiers and their allies, on the run, had destroyed in their retreat from the invaders' offensive. One emblematic image (resulting from the episode of the visit made by the Emperor Wilhelm II on the Romanian front) is that of the oilfields on the Prahova Valley. In late 1916, the refineries in Ploieşti had been damaged beyond recognition. In the extraction area, no pump seemed to have been left working. Destroyed equipment, oil tanks set on fire. This was all that the Romanian authorities had left behind them. It was therefore due to the Germans that the Romanian oil industry had miraculously returned to life. Production soon was resumed and an entire compound of administrative departments, infirmaries, prison camps, soldiers' barracks and delousing facilities cropped up in Câmpina. "The merry song of work" could be heard everywhere. The drill was roaring in the deep, and the piston descended fast as an arrow into the well, until the engine pulled it back up, heaving, and the thick crude flowed into the pipe. ${ }^{22}$ Nowhere (not even later on, in communist times) could one find a more grandiose portrayal!

18. ANGELOW, 2007, p. 135.

19. PADDOCK, 2014, p. 222-246, here p. 243.

20. RWB, 1. Jahrgang, no 1, 12 Mai 1917, p. 2-3.

21. MAYerhofer, p. 329.

22. RWB, 1. Jahrgang, no. 19-20, Bukarest 20 Oktober 1917, p. 21-25. 
CAHIERS BALKANIQUES

\section{The image of Germany's allies}

The dissemination of positive images about the allies (the Bulgarian, Turkish and Austro-Hungarians comrades) in order to strengthen cohesion is a common note in coalition wars. Under military occupation, Romania became a country where soldiers with different education, religion and nationalities come together. Quite a lot of friction was present within the coalition of the Central Powers from the very first weeks of the Romanian campaign. The disagreements between the Germans and the Bulgarians and the minimization of Turkey's military contribution were commonplace topics. The occupation press (and particularly RWB) attempted to defuse cultural disputes by publishing articles sending a tolerant and benevolent message. The Bulgarian allies are the object of the most ample stories. The magazine published articles about the industrialization of Bulgaria, about its spiritual life, about the Bulgarian soldiers, their war songs, about Bulgaria's roses, its arts and poetry, even a portrait of the Tsar Ferdinand I and heroes of liberty (Hristo Botev). ${ }^{23}$ Next come the Turks. The magazine writes extensively about the Turks' participation in the Romanian campaign, introduces the readers to the "Turkish greeting", discovers the Turkish press, the Turkish women and cuisine, and, above all, the personality of the Turkish people. The issue dedicated to Turkey boldly sets on its cover the portrait of the Sultan (Mehmed v), whom it portrays generously. Next comes an incursion in the biography of Enver Pasha, the minister of war (called by the publication "the Napoleon of Islam" and "the Saviour of the Motherland"!), of Talaat Pasha, the Great Vizier, flanked in photographs by other personalities from the top ranks of the empire (Ahmed Nessimy Bey, the foreign minister, Dschavid Bey, the finance minister, Rifaat Bey, president of the Senate, Hadji Adil Bey, president of the Chamber etc.) and of Osman Nizamy Pasha, general-lieutenant, Turkey's chargé d'affaires in the military administration of Romania, himself presented as "one of the most worthy" leaders of new Turkey, an energetic and wise individual. ${ }^{24}$ Finally, a portrayal of Austria-Hungary completed the picture. A delicate topic, with also touched Romanian sensitivities to the core. The German propaganda however cleverly makes its presence felt. The articles dedicated to Austria-Hungary pursue two distinct goals: one the one hand, the editors condemn Romania's intervention into the war, which they see as a regrettable deviation from the "amiable" course of the relationship with the Double Monarchy, and on the other hand the reader discovers at every step the proof of the "harmonious" cooperation between the Germans and their

23. RWB, 1. Jahrgang, no. 13, Bukarest, 25 August 1917.

24. RWB, 1. Jahrgang, no. 17-18, Bukarest 22-23 September 1917. 
Austro-Hungarian allies, who make every effort to put to good use Romania's riches and to help its economic recovery. In the article titled „Historische und politische Beziehungen zwischen Rumänien und Österreich-Ungarn"/Historical and political relations between Romania and Austria-Hungary", the author (Heinrich Hisk) evokes the past attempts made by the Saxons, the Szekely and the Hungarians to colonize the space East of the Carpathians, and talks about the earliest proofs of the presence of Germans in Bucharest (late 1 $17^{\text {th }}$ century and early $18^{\text {th }}$ century). The modern history of bilateral relations seems to show that Austria-Hungary had provided Romania with economic and political support, understood, however, as fundamental guarantees for an uninterrupted development. The guarantee of friendly relations, above and beyond treaties, was the friendship between the royal families. Emperor Franz Joseph's visit to Sinaia (1896), followed by that of Archduke Franz Ferdinand (1909) together with princess Sofia, were discussed in context. Another article focused on the economic cooperation of the Central Powers in Romania. It is worth noting the manner in which these events were portrayed. In a defeated country, deserted by its administration and government, the population left behind faces famine and exile. However, the conqueror had not been handed the spoils of war, but instead the burden of hardship. But a country like Romania cannot turn into a desert. Out of the smoking ruins arose the country's renewed will to live. The broken bridges were either repaired or replaced, the mines and the wrecks on the Danube were cleared, the rigs in the oilfields were made to work again, through the miracle of technology, the fields were ploughed and sowed anew. Since the start of the occupation, with a lofty feeling of responsibility, the Central Powers were guided by the intention of not using their rights as conquerors in order to enforce a vengeful rule. The fate of the disarmed people became a matter of survival, in the service of which the German and Austro-Hungarian officials placed all their capacity. The workforce, order and safety were back in their places, and the allies of the Danube Monarchy had their contribution. Immediately after the military administration was established, Austria-Hungary was assigned several missions. The Austro-Hungarian delegates to the military government of Romania had the task of unifying the institutions, forces and organizations of the Danubian Monarchy. Those who served them were (apart from commanding officers) public servants, engineers, doctors, managers, members of the consular missions of the Foreign Ministry, along with a whole host of counsellors in all economic matters. ${ }^{25}$

25. RWB, 1. Jahrgang, no. 21, Bukarest, 17 November 1917, p. 4-8. 
CAHIERS BALKANIQUES

La presse allophone dans les Balkans

\section{$R W B$ / A source of information}

When they run out of topics written in exclusively propagandistic tones, the texts published in the magazine switch to the informative register. RWB gets the Germans acquainted with the image of Romanians as a people; it describes in detail the settlements and homes, the traditional attire, the Romanian's disposition and nature, the Romanian cuisine, it talks about personalities of politics and culture. The narrative trend highlights an interest for building a durable bond. The magazine fosters the perception of Romania as a rich country with a peaceful people; there was an aspiration to bridge, in the future, the gaps between the invading foreigners and the occupied country. The magazine shows great interest in describing traditional households, the village universe, the traditional clothing, the folk traditions and customs. ${ }^{26}$ Other information relates to the local currency and the characteristics of the climate. ${ }^{27}$ The general effort towards comprehension is remarkable. The war had facilitated an encounter between the German world and the Romanian specific traits that politics and cultural personalities had not managed before. It is hard to assess what readership and reach the magazine had in the era. Nevertheless, we can assume that the significant events of the war were the only one to arouse the genuine interest of the readers. Thinking about their families and about those left behind at home, the soldiers waited impatiently for news from the frontlines. After three years of war that had almost drained the nation's morale resources, the Germans had become very sensitive to any rumours about an impending peace. The news concerning the Bucharest Peace Treaty would most likely have piqued the interest of the readers. But the magazine editors made insufficient efforts: the peace talks were reflected only frugally for the German audience, with few comments and mainly through photographs. The issue of 21 March 1918 published on its cover the portraits of the four heads of the Central Powers coalition delegation. Then came a few valuable photographs of the delegation members, including the Romanian plenipotentiaries. The actual contents of the talks were skilfully avoided. The magazine published an extensive article about prince Barbu Stirbey's castle in Buftea, then skipped to another topic: German actors on the stage of the National Theatre in Bucharest. ${ }^{28}$

26. RWB, 1. Jahrgang, no. 6, Bukarest, 14 Juni 1917 (Rumänischer Bauernhäusern), p. 13-14; no. 8, Bukarest, 7 Juli 1917 (Regen, Dürre,und Volksaberglaube in Rumänien), p. 14-16;

no. 12, Bukarest, 4 August 1917 (Geburt und Tod bei Rumänen), p. 6-8.

27. RWB, 1. Jahrgang, no. 11, Bukarest 28 Juli 1917, p. 2-3.

28. RWB, 2. Jahrgang, no. 5, Bukarest, 21 März 1918, p. 7. 
The topic of peace returned however to the spotlight once the treaty was signed. The 31 May 1918 edition had on its cover the redemptive photograph of the document signing, followed by a number of one-of-a-kind pictures showing the delegates arriving at Cotroceni. The absence of comments in the German-language publication is striking. ${ }^{29}$ Things looked entirely different in the Romanian version, "Săptămâna Ilustrată": after granting ample space to the Brest-Litowsk ${ }^{30}$ talks and even attempting a recollection of all the main peace talks in history, ${ }^{31}$ the magazine focused on the signing of the Romanian peace. This time, the course of events was accounted and the main litigious points being discussed were listed. ${ }^{32}$ The signing was celebrated in a special edition, in which the photographs had captions, the conclusion being that the peace was ending a war in which the people had been unjustly thrown. All eyes were looking to the future, where old friendships could be resumed. But the new Romania would be built on the ruins of inauspicious politics. ${ }^{33}$ The signing of the Bucharest peace had provided the German press a new propaganda vision. The German soldier identified now his sacred mission: preserving the guarantees of the new political construction.

But no less important is your duty today than it was before the war. You are the guardians of peace, the legacy of so many dead and crippled comrades-in-arms. It is for you, those who remain, to fight the economic battle for the prosperity of the fatherland. Do not let yourselves fooled by the image of peace. The gates of peace are not yet open. The battle for victory has been unleashed in the West, and this victory must bring our country a secure future, and to our people - the unhindered development of its strengths and abilities. You must remain strong and steeled in your minds, for every new day may send you to the Western frontlines as combatants, and therefore trust, bodily strength and maximum resolve shall be required from you. Bear in mind that over there, not far from Paris, blood is flowing. ${ }^{34}$

29. RWB, 2. Jahrgang, no. 8, Bukarest, 31 Mai 1918.

30. "Săptămâna ilustrată" year II, nr. 27, Bucharest, 23 January 1918.

31. "Săptămâna ilustrată" year II, nr. 30, Bucharest, 22 February 1918.

32. "Săptămâna ilustrată" year II, nr. 33, Bucharest, 23 March 1918.

33. "Săptămâna ilustrată" year II, nr. 37, Bucharest, 12 June 1918.

34. "Rumänische Feldpost. Soldatenzeitung für besetzte Rumänien”, 1. Jahr., no. 1, Bukarest, 1 Juli 1918. See Kamaraden (Call to comrades), p. 1. 
CAHIERS BALKANIQUES

La presse allophone dans les Balkans

\section{Conclusion}

RWB had a special place in the press landscape during the military occupation. The publication aimed to prepare the mindset of the time for the full integration of the Romanian space into the German projects concerning the reorganisation of South-East Europe. The mechanism of this "integration" had been designed in Berlin during the war years and would have worked only in the event that Germany won. As the Entente allies' successes became increasingly evident, the magazine's mission appears to be compromised. RWB stopped being published once Mackensen's army retreated. What it left behind is significant. RWB had seriously shaken the conventional barriers of Romanian journalism, it had shattered everything that the national propaganda had built during the neutrality years. We are now certain that this publication, in a foreign language, systematically projected in the imagination its contemporaries, the future of a new Romania. What would things have been like, had Germany won the war? This virtual image obviously clashed with the Romanians' expectations, or at least with the expectations of a considerable part of the population. The moral crisis had been dealt with in depth. The local population had to be helped to understand (with the help of the Romanian-language version) the difference between the past and the present. The country had changed for the better: its cities were becoming cleaner, the resources were distributed in a more equitable manner, roads and highways were being repaired, the peasants worked joyfully in the fields. From a country filled with natural riches, but with an impoverished population, Romania would change its image. Under German direction it would become prosperous and strong. The Europeanization "started" during the reign of king Carol I could thus be completed. As utopian as this construction appeared to some, as realistic it appeared to others (radicalist Germanophiles still in Bucharest), judging from the situation on the front. Soon, however, the frontline collapsed and the dream of change took on different hues. We may never know whether or not we shunned a fate that would have been more becoming for us. But this is what the end of the war decided. A matter of destiny.

\section{Bibliography}

\section{Books}

Hentea Cătălin, 2014, Propaganda în război, Cetatea de Scaun, Târgovişte, $534 \mathrm{p}$. 
Koszyk Kurt, 1968, Deutsche Pressepolitik im Ersten Weltkrieg, Droste, Düsseldorf, $288 \mathrm{p}$.

Lipp Anne, 2003, Meinungslenkung im Krieg. Kriegserfahrungen deutscher Soldaten und ibre Deutung 1914-1918, Vandenhoeck \& Ruprecht, Göttingen, $354 \mathrm{p}$.

Mayerhofer Lysa, 2010, Zwischen Freund und Feind. Deutsche Besatzung in Rumänien 1916-1918, Peter Lang GmbH, Internationaler Verlag der Wissenschaften, Berlin, $412 \mathrm{p}$.

Nelson Robert, 2011, German Soldiers Newspaper of the First World War. Cambridge University Press, New York, 280 p.

Tudorancea Radu, 2016, Frontul de acasă. Propagandă, atitudini şi curente de opinie în România Primului Război Mondial, second edition, revised and amended, Eikon, Bucharest, 300 p.

Tzigara-Samurcaş Alexandru, 1999, Memorii, vol. ii (1910-1918), critical edition by Ioan Șerb and Florica S,erb, foreword by Dan Grigorescu, Grai şi Suflet, Bucharest.

Velburg Gerhard, 1930, Rumänische Etappe. Der Weltkrieg wie ich sah, Wilhelm Köhler Verlag, Minden, 324 p.

\section{Papers and contributions to books}

ANGELOW Jürgen, 2007, „Die Mittelmächte im Rumänienfeldzugvon 1916/1917. Kulturelle Transfers und Erinnerungskultur", in Militärgeschichtliches Zeitschrift, 66, p. 132-144.

BARThel Christopher, 2014, "Cultivation of Deutschtum in occupied Lithuania”, in PAddock Troy (ed.), World War I and Propaganda, Brill, Leiden-Boston, p. 222-246, 360 p., DOI: 10.1163/9789004264571

Fassel Horst, 2016, „Die feldgrauen Musen. Duetsche Kultureinrichtungen im besetzten Rumänien (1916-1918)“, Studia Germanica Napocensia, Presa Universitară Clujeană, Cluj, 368 p. 


\section{CAHIERS BALKANIQUES}

98 La presse allophone dans les Balkans

GaHlen Gundula, 2009, „Erfahrungshorizonte deutscher Soldaten im Rumänienfeldzug 1916-1917“, in Gross Gerhard P. \& PAHL Magnus, Am Rande Europas? Der Balkanr-Raum und Bevökerung als Wirkungsfelder militärischer Gewalt. Im Auftrag des Militärgeschichtlichen Forschungsamtes, De Gruyter Oldenbourg, München, p. 137-159, 436 p.

Bucur Maria, 1999, "Romania: war, occupation, liberation,” in Roshwald Aviel \& Stites Richard (eds.), European Culture in the Great War, Cambridge University Press, p. 243-367, 444 p.

\section{Press}

RWB (Rumänien im Wort und Bild,) 1. Jahrgang, no 1, 12 Mai 1917, p. 2-3.

RWB, 1. Jahrgang, no. 6, Bukarest, 14 Juni 1917 (Rumänischer Bauernhäusern), p. 13-14.

RWB, 1. Jahrgang, no. 8, Bukarest, 7 Juli 1917 (Regen, Dürre, und Volksaberglaube in Rumänien), p. 14-16.

RWB, 1. Jahrgang, no. 11, Bukarest 28 Juli 1917, p. 2-3.

RWB, 1. Jahrgang, no. 12, Bukarest, 4 August 1917 (Geburt und Tod bei Rumänen), p. 6-8.

RWB, 1. Jahrgang, no. 12, Bukarest, 4 August 1917 (Geburt und Tod bei Rumänen), p. 6-8.

RWB, 1. Jahrgang, no. 13, Bukarest, Sondernummer Bulgarien, 25 August 1917.

RWB, 1. Jahrgang/ Doppelnummer, Sonderheft: Die Türkei, no. 17-18, Bukarest, 22-23 September 1917.

RWB, 1. Jahrgang, no. 19-20, Kaisernummer, Bukarest, 20 Oktober 1917, p. 21-25.

RWB, 1. Jahrgang, no. 21, Bukarest, 17 November 1917, p. 4-8.

RWB, 2. Jahrgang, no. 5, Bukarest, 21 März 1918, p. 7. 
RWB, 2. Jahrgang, no. 8, Bukarest, 31 Mai 1918.

Rumänische Feldpost. Soldatenzeitung für besetzte Rumänien, 1. Jahr., no. 1, Bukarest, 1 Juli 1918. (Call to comrades), p. 1.

Săptămâna ilustrată year II, nr. 27, Bucharest, 23 January 1918.

Săptămâna ilustrată year II, nr. 30, Bucharest, 22 February 1918.

Săptămâna ilustrată year II, nr. 33, Bucharest, 23 March 1918.

Săptămâna ilustrată year II, nr. 37, Bucharest, 12 June 1918.

\section{Archives}

Romanian Military Archives, fonds "Marele Cartier General" ("General Headquarters"), file nr. 1195, leaves 13-14. See, ”Propaganda germană pe frontul român”. Document issued by the Intelligence Department, 1917.

Abstract: The German press in Romania during the Occupation, only occasionally found its way into historical research. About Rumänien in Wort und Bild, very little has been written. What is known is that, shortly after Bucharest was occupied, the German Headquarters worked to reorganise its propaganda. One of the military occupation newspapers was Rumänien im Wort und Bild, a weekly magazine used intensively as an information instrument. The first issue of the magazine (12 May 1917) stated that the publication aimed to serve the German officers and the soldiers of the allied armies as a would-be guide to the conquered territory. Meanwhile, it targeted the local German inhabitants and the subjects of the allied powers, who were offered the opportunity to recount to the "German fatherland" their experiences in a country that the "victorious campaign" hoped to make rich and fertile again. To the Romanians, the magazine would show how compassionate the Germans, the exponents of a foreign culture, had been in their dealings with the locals. This study analyses the main topics of the publication, attempting to place it in the Romanian context of the occupation press and of the frontline newspapers.

Keywords: First World War, Occupation press, propaganda, Roumania, Rumänien im Wort und Bild 
Résumé : la presse allemande pendant l'Occupation en Roumanie a peu trouvé sa place dans la recherche historique, on a très peu écrit sur le Rumänien im Wort und Bild. Ce que l'on sait, c'est que peu après l'occupation de Bucarest, l'État-major allemand travailla à réorganiser sa propagande. Le Rumänien im Wort und Bild, fut l'un de ces journaux d'Occupation, un hebdomadaire intensément utilisé comme journal d'information. Son $1^{\text {er }}$ numéro, le 11 mai 1917, précise qu'il vise à servir de guide du pays conquis aux soldats allemands et à leurs alliés. Il vise en même temps la population locale allemande et ses alliés et veut leur offrir l'occasion de faire connaître à la «mère-patrie » allemande leurs expériences d'un pays que la « campagne victorieuse » va rendre riche et fertile. Aux Roumains, l'hebdomadaire montrera à quel point les Allemands, exemples d'une culture étrangère, sont pleins de compassion dans leurs rapports avec les autochtones. Cette étude analyse les principaux thèmes de la publication, en les replaçant dans le contexte de la presse roumaine d'Occupation.

Mots-clefs : presse d'occupation, Première Guerre mondiale, propagande, Roumanie, Rumänien im Wort und Bild

Rezumat: Presa germană din România, în anii ocupației militare, s-a infiltrat numai ocazional în cercetările istorice. Despre Rumänien in Wort und Bild istoricii au reținut foarte puțin. Se cunoaște că, la scurt timp după ocuparea Bucureștilor, Comandatura Germana s-a preocupat de reorganizarea propagandei. In fostul local al cotidianului "Adevărul" se tipăreau ziarele regimului de ocupație militară. Printre acestea, Rumänien im Wort und Bild, o revistă săptămânală, folosită intens ca instrument de informare. Primul număr al publicației (12 mai 1917) arată că revista ișsi propunea să servească ofițerilor germani și soldaților din armatele aliate asemeni unui ghid in teritoriul cucerit. In același timp, ea se adresa germanilor autohtoni și supuşilor puterilor aliate, care aveau ocazia de a-și povesti în "patria germană" experiența proprie trăită intr-o țară pe care "campania victorioasă" sperau că o va face din nou bogată și roditoare. Românilor revista le-ar fi arătat cu câtă compasiune au fost tratați de germanii, purtători ai unei culturi străine. Acest studiu analizează subiectele și tematica publicației, incearcă să o integreze în tabloul românesc al presei de ocupație și al ziarelor de front.

Anabtar kelimeler: Romanya, işgal basını, Biwrinci Dünya Savaşı, Rumänien im Wort ve Bild, propaganda

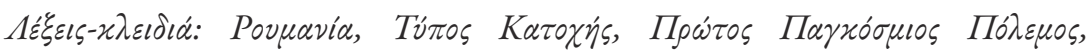
Rumänien im Wort und Bild, $\pi \rho \circ \pi \alpha \gamma \alpha \dot{\nu} \delta \alpha$

Кяучни зборови: Романија, Окупаторски печат, Прва светска војна, Rumänien im Wort und Bild, пропаганда 